\title{
Placental Growth Hormone-Related Proteins and Prolactin-Related Proteins
}

\section{Citation}

Haig, D. 2008. Placental growth hormone-related proteins and prolactin-related proteins.

Placenta 29: 36-41.

\section{Published Version}

doi:10.1016/j.placenta.2007.09.010

\section{Permanent link}

http://nrs.harvard.edu/urn-3:HUL.InstRepos:11148777

\section{Terms of Use}

This article was downloaded from Harvard University's DASH repository, and is made available under the terms and conditions applicable to Other Posted Material, as set forth at http:// nrs.harvard.edu/urn-3:HUL.InstRepos:dash.current.terms-of-use\#LAA

\section{Share Your Story}

The Harvard community has made this article openly available.

Please share how this access benefits you. Submit a story.

\section{Accessibility}




\title{
Placental growth hormone-related proteins and prolactin-related proteins.
}

\author{
David Haig \\ Department of Organismic and Evolutionary Biology, \\ Harvard University, \\ 26 Oxford Street, Cambridge MA 02138.
}

e-mail: dhaig@oeb.harvard.edu

phone: 617-496-5125

fax: 617-495-5667

Keywords: GH, PRL, placenta, endometrial glands, placental lactogen 
The placentas of ruminants and muroid rodents express prolactin (PRL)-related genes whereas the placentas of anthropoid primates express growth hormone (GH)-related genes. The evolution of placental expression is associated with acclerated evolution of the corresponding pituitary hormone and destabilization of conserved endocrine systems. In particular, placental hormones often evolve novel interactions with new receptors. The adaptive functions of some placental hormones may be revealed only under conditions of physiological stress. 


\section{Introduction}

Placental hormones are produced by offspring, but act on receptors of mothers. As such, placental hormones and maternal receptors are prime candidates for the expression of parent-offspring conflict [1,2]. The placenta is selected to secrete hormones into the mother's circulation only if the hormones modify maternal physiology in ways that benefit the fetus, but maternal responses evolve to maximize maternal fitness. This paper will examine the actions of two ancient vertebrate hormones, and of placental versions of these hormones that have evolved independently in at least three groups of mammals.

Growth hormone (GH) and prolactin (PRL) are structurally-related molecules with structurally-related receptors (GHR and PRLR). GH and PRL exhibit highly divergent rates of molecular evolution in different mammalian lineages. In most mammals, these hormones are evolutionarily conservative, with a slow rate of amino acid substitutions. But, in at least three lineages - anthropoid primates, muroid rodents, and ruminants either GH, PRL, or both have undergone greatly accelerated evolutionary change. And, in all three lineages, GH-derived or PRL-derived genes are expressed in the placenta and signal via maternal GHRs or PRLRs. The accelerated evolution of GH and PRL in these lineages may reflect ongoing maternal-fetal conflict.

\section{Growth hormone and prolactin}

Growth hormone was so named because extracts from bovine pituitaries accelerated growth when administered to rats. But, the name may mislead as much as it informs: mammals continue to produce $\mathrm{GH}$ after they have reached adult size; exogenous GH suppresses rather than enhances growth in poultry [3]; and fasting elevates GH, but reduces growth, in teleost fishes [4]. In humans, basal GH is increased in kwashiorkor, marasmus, anorexia nervosa, and fasting. Growth and starvation are both situations in which a lipid-rich body would benefit from conserving amino acids rather than using them as substrates for gluconeogenesis. The primary function of GH may be to shift the body's fuel preference from glucose to lipids [5].

Prolactin was so named because pituitary extracts induced lactation in mammals and production of 'crop-milk' in pigeons [6]. PRL also stimulates secretion of 'uterine milk' by the endometrium of rabbits and pigs [7,8], and PRLRs are present on endometrial glands of women, baboons, and sheep [9-11]. Decidual stromal cells of women and Old World monkeys produce PRL [10,12], but decidual PRL does not significantly enter the maternal or fetal circulation [13]. PRLRs are expressed on glandular epithelia and 
natural killer cells of the human decidua $[9,14]$. Therefore, a plausible hypothesis is that endometrial glands and decidual NK cells are the principal targets of PRL produced by the decidual stroma [15].

PRL is said to have more disparate actions than all other pituitary hormones combined [16]. Some patterns emerge, however. The promotion of parental behaviors [17,18], the elevation of PRL after coitus in rodents, rabbits, and humans [19-21], and the suppression of ovarian function and libido by hyperprolactinemia [22], all suggest that an ancient function of PRL may have been to shift the body's priorities away from reproduction (in the narrow sense of mating and ovulation) toward other fitnessenhancing activities.

\section{Ligand/receptor interactions}

PRL and GH signal by a process of sequential binding to two receptors. Each hormone has two receptor-binding sites. A molecule of unbound hormone initially binds via site 1 to the first receptor, forming a 1:1 complex. Only then is the hormone able to bind via site 2 to a second receptor, forming the active 1:2 complex. Unbound receptors can either bind to site 1 of a free hormone to form a 1:1 complex or to site 2 of a bound hormone to form a 1:2 complex. The likelihood of these different fates is determined by the relative abundance of free hormones and 1:1 complexes, and by the relative affinities of site 1 and site 2 for unbound receptors [23].

The process of sequential dimerization introduces complexities when interpreting whether a given hormone is acting as an agonist or an antagonist of GHRs or PRLRs, especially when multiple hormones compete for the same receptors. Each additional molecule of a hormone may facilitate or obstruct the formation of active 1:2 ligandreceptor complexes depending on the frequency of unbound receptors. A hormone that, by itself, acts as a weak agonist may nevertheless antagonize the action of a second hormone with stronger agonist activity.

\section{PRIMATES}

Bushbaby GH differs from porcine GH by only four residues whereas human $\mathrm{GH}$ and porcine GH differ by 66 residues [24]. Thus, GH has changed little in the lineage leading to bushbabies but has undergone dramatic change in the lineage leading to humans since these lineages diverged from a common ancestor. Strepsirrhine primates, such as bushbabies, have a single evolutionarily conservative $\mathrm{GH}$ gene [24,25] whereas 
anthropoid primates, such as humans, have multiple GH-related genes that have undergone rapid evolutionary change [26].

Neither strepsirrhine nor anthropoid PRL loci have been duplicated, but these hormones exhibit a similar contrast in evolutionary rates to that observed for GH. Strepsirrhine PRLs are evolutionarily conservative whereas anthropoid PRLs have undergone a period of rapid evolution after the divergence of strepsirrhine and anthropoid primates, but before the separation of New World and Old World monkeys [27]. In parallel with its ligand, the PRLR has undergone accelerated evolution in anthropoid primates [28].

Growth hormones of humans, macaques, and squirrel monkeys bind to PRLRs as well as to GHRs, and are active in lactogenic (PRLR) as well as somatogenic (GHR) bioassays [29,30]. The lactogenic activity of anthropoid GHs implies that these hormones bind to two PRLRs via site 1 and site 2 . An important evolutionary question is whether the initial mutation that conferred affinity for PRLR via site 1 was associated from the start with affinity for a second PRLR via site 2 or whether site- 2 affinity was aquired subsequently. In the latter scenario, the initial mutation would have produced a $\mathrm{GH}$ that functioned as an antagonist of PRLRs by binding at site 1, but not at site 2 .

Anthropoid primates possess a cluster of GH-related genes [31,32]. All genes of a cluster are, strictly speaking, orthologs of the single GH gene of other mammals. But, one gene is usually singled out as the 'true' GH, based on its expression in pituitary somatotrophs. The additional genes of apes and Old World monkeys are expressed in the placenta $[32,33]$ but this has not been determined in New World monkeys. All GHlike proteins of New World monkeys are more similar to each other than to any GH-like protein of apes or Old World monkeys, suggesting independent duplications of GH in the two lineages [34].

The growth hormone gene cluster of humans contains a single gene expressed in the anterior pituitary $(G H 1)$ plus four genes expressed in the placenta $(C S H L 1-C S H 1-$ GH2 - CSH2). GH1 encodes human growth hormone (hGH), GH2 encodes human placental growth hormone (hPGH), and $\mathrm{CSH} 1$ and $\mathrm{CSH} 2$ encode human placental lactogen (hPL) [32]. These hormones have different relative affinities for GHRs and PRLRs: hGH binds to both GHRs and PRLRs; hPL has high affinity for PRLRs but very weak affinity for GHRs [35]; and hPGH has high affinity for GHRs but negligible affinity for human PRLRs [36]. The simplest scenario is that the GH of an ancestral anthropoid primate bound promiscuously to GHRs and PRLRs. Promiscuous binding has been preserved by pituitary GH. In this scenario, hPL has evolved fidelity for PRLRs, and hPGH fidelity for GHRs, by a process of gene duplication and subfunctionalization. 
During human pregnancy, the placenta secretes a ligand of maternal GHRs (hPGH) and a ligand of maternal PRLRs (hPL). Concentrations of both ligands increase with advancing gestation. In the latter stages of pregnancy, the maternal pituitary has almost ceased producing hGH but produces hPRL at higher levels than in the nonpregnant state [37,38]. Maternal GH and PRL thus exhibit contrasting responses to pregnancy. As a result, maternal GHRs encounter only their placental ligand (hPGH) whereas maternal PRLRs encounter high levels of both maternal and placental ligands (hPRL and hPL).

Concentrations of IGF-I and hPGH in maternal serum are tightly correlated in the second half of human pregnancy [39]. Therefore, hPGH acts as an agonist of maternal GHRs. The suppression of maternal pituitary hGH, as placental production of hPGH escalates, suggests that natural selection acting on mothers has favored reduced signaling via GHRs whereas natural selection acting on fetuses has favored increased signaling [2]. This hypothesis could explain why site 1 of hPL has lost its affinity for GHRs, because otherwise the colossal production of hPL near term would strongly antagonize fetallyfavored responses via maternal GHRs (by blocking receptor dimerization).

What benefits do human fetuses gain by activating maternal GHRs? As yet, no definitive answer can be given to this question, but some evolutionary hypotheses can be suggested. Among the known effects of hGH are increased lipolysis, increased hepatic output of glucose, and increased peripheral resistance to insulin. hPGH elicits similar effects in experimental systems $[40,41]$. Thus, hPGH may act in concert with other placental hormones to augment the supply of fatty acids and glucose to the placenta. Human mammary glands express both GHRs and PRLRs [42]. Thus, mammary GHRs are another possible target of hPGH.

PRLRs are expressed on glandular epithelia and uterine natural killer cells of the human decidua [9,14]. These PRLRs are targets for hPL produced by extravillous trophoblast [41] and hPRL produced by the decidual stroma [12]. Synctiotrophoblast is the source of hPL released into the general maternal circulation [44]. Many maternal tissues express PRLRs and are possible targets of circulating hPL.

The key question for understanding the function of hPL in pregnancy is whether hPL acts as an agonist or antagonist of PRLRs at the physiological concentrations of hPL and $\mathrm{hPRL}$ present during pregnancy. I have vacillated on this question. I initially proposed that the function of hPL was to activate maternal PRL receptors for fetal benefit [1]. At that time, I had not recognized the significance of elevated maternal hPRL, nor had I recognized the possibility that an abundant placental hormone could act as an antagonist of maternal receptors. If maternal PRL receptors do not discriminate between hPL and 
hPRL, the genetic-conflict hypothesis predicts that maternal production of hPRL should decrease in response to increasing placental production of hPL, contrary to observations. However, the hypothesis is compatible with elevated production of both hormones if one functions as an agonist and the other as an antagonist [2].

\section{Ruminants}

Both GH and PRL have undergone rapid evolution in the lineage leading to ruminants $[26,45,46]$. PRL is duplicated in all well-studied ruminants whereas most species have a single GH-like gene. Therefore, accelerated evolution of GH is observed in the absence of gene duplication. The cluster of PRL-like genes contains a gene expressed in the pituitary (PRL) and a 'placental lactogen' (PL), as well as prolactin-related proteins (PRPs) [47-49]. At least some, perhaps all, PRPs are expressed in the placenta. Ruminant PLs bind to both PRLRs and GHRs. They act as agonists of PRLRs but as antagonists of GHRs [50]. Ovine PL (oPL) can to bind to GHR via site 1 and PRLR via site 2 to form a GHR/PL/PRLR complex [51].

PRLRs are expressed on the glandular epithelia of ruminant endometria [11]. oPL binds to endometrial PRLRs and increases the secretion of 'uterine milk' into the uterine lumen [52-54]. Stimulation of uterolactation does not require PL to enter maternal blood. Thus, bovine PL is present at high concentrations in uterine fluids but is barely detectable in serum of pregnant cows $[55,56]$. Substantial quantities of oPL enter the circulation of pregnant ewes [57], raising the possibility that oPL targets PRLRs at extrauterine sites.

Rapid change of GH occurred in the period after ruminants diverged from their common ancestor with hippos and whales, but before chevrotains diverged from other ruminants [58,59]. The reason for the burst of adaptive change in GH is unknown but I conjecture that this is a consequence of the destabilization of ligand-receptor relations caused by PLs binding to GHRs. Domestic sheep and goats are polymorphic for a duplication of GH [60]. On haplotypes with two GH genes, one gene is expressed in the pituitary and the other in the placenta [61].

\section{Muroid Rodents}

Molecular evolution of GH is only modestly accelerated in muroid rodents whereas the evolution of PRL has been dramatically accelerated $[45,46]$. GH is represented by a single gene in rodent genomes but PRL has given rise to a large cluster of genes, most of which are expressed in the placenta. The PRL-related gene clusters of rats and mice 
each contain more than 20 genes, known by various names including placental lactogens (PLs), PRL-like proteins (PLPs), and proliferins (PLFs) [62]. Rodent PRL and PLs bind to PRLRs, whereas PLPs and PLFs bind to other, currently unidentified, receptors. This section will focus on 'classical' effects of PLs via maternal PRLRs before briefly discussing non-classical actions of PLPs and PLFs.

Muroid rodents have very short estrus cycles that are an adaptation for the rapid production of a new 'clutch' of eggs if mating fails. In the process, PRL has acquired a luteotrophic function that is perhaps unique to this group of mammals. Corpora lutea of unmated females are rapidly suppressed by activation of the progesterone-degrading enzyme $20 \alpha$-hydroxysteroid dehydrogenase (20 $\alpha$ HSD). PRL, and rodent PLs, bind to ovarian PRLRs and cause the inhibition of $20 \alpha$ HSD [63]. The source of luteotrophic PRL shifts during the course of a pregnancy. Coitus on the day of ovulation induces twice daily surges of PRL from a female's anterior pituitary that maintain corpora lutea [19]. However, as pregnancy progresses, the luteotrophic effects of decidual PRL are supplemented by those of placental lactogens [64]. Rodent PLs may also confer benefits on offspring via PRLRs in other maternal tissues. Obvious candidates are actions on mammary glands [65] and the maternal brain [18].

Proliferin (PLF) and proliferin-related protein (PRP) bind to endothelial cells and have angiogenic and anti-angiogenic actions respectively. PLF is produced by the placenta in mid gestation and PRP in late gestation [66]. These molecules may function to increase and maintain maternal blood flow to the placenta [67]. Other things being equal, the recruitment of additional vessels to the implantation site will increase blood flow, whereas lengthening of existing vessels, or narrowing of their radius, will reduce flow.

Prolactin-like protein-A (PLP-A) is expressed in secondary trophoblast giant cells [68]. PLP-A binds to uterine natural killer cells in rats and inhibits the production of interferon $\gamma[69]$. Plpa has been inactivated in mice with intriguing results. Under normal rearing conditions, homozygous null mothers with homozygous null litters successfully complete pregnancy. However, null litters aborted when null mothers were placed in hypobaric oxygen from day 7.5 of pregnancy whereas wild-type mothers, with wild-type litters, successfully completed pregnancy under the same conditions [70]. I conjecture that the physiological stress of hypoxia activates a facultative response of uterine natural killer cells to abort the pregnancy but this mechanism is blocked in wild-type mice by placentally-produced PLP-A. (In a similar vein, genetic deletions of hPL have little effect on the pregnancies of well-nourished women [71]. Perhaps, the crucial adaptive role of hPL will be revealed only in conditions of severe physiological stress.) 
In litter-producing species, evolutionary forces differ between placental hormones with paracrine effects at the maternal-fetal interface and placental hormones with endocrine effects at extrauterine sites. In the former case, the benefits of hormone production accrue directly to the producer whereas, in the latter case, the benefits are shared with other members of the litter. Production of a hormone with systemic maternal effects is a cooperative enterprise among the members of a litter. Offspring may be selected to skimp on their contribution to the 'collective good' because marginal benefits are shared but marginal costs are borne by each offspring individually [2].

\section{Placental hormones and maternal-fetal conflict}

Placental expression of GH- or PRL-related genes is correlated with accelerated evolution of GH and/or PRL. Accelerated evolution is not a mere side-effect of gene duplication because it is also observed for single-copy genes, such as the PRLs and PRLRs of anthropoid primates. Further comparative studies should provide greater resolution on the relative timing of accelerated evolution, gene duplications, placental expression, and changes in placental morphology.

Mother and fetus 'disagree' about the precise settings on homeostatic controls in the mother's body. Placental hormone expression evolves to adjust these settings and maternal receptors and counter-hormones evolve to nudge the settings back toward the maternal optimum. If such a system reaches an evolutionary equilibirum, this state will be one in which both sides have taken all simple moves to adjust the controls in their favor. Such a state is likely to be unresponsive to fluctuations in the mother's condition and not easily perturbed. These considerations may help to explain why placental hormones are produced in such large amounts and in amounts that vary little from moment to moment. On the time-scale of hours, even days, the release of placental hormones is constitutive rather than facultative.

Under optimal conditions, the divergence of interests between mother and fetus may be small; no more than a petty squabble over precisely how much glucose and lipid a fetus should receive, when both are in abundant supply. However, when the mother is physiologically threatened, maternal and fetal interests can diverge markedly. For instance, mother and fetus may differ in the amount of 'collateral damage' to trophoblast each is prepared to countenance in the course of combating an intrauterine infection. From the evolutionary perspective of the fetus, this is an existential threat but, from the evolutionary perspective of mothers, aborted offspring are partially replaceable when conditions improve. 
The absence of a placental hormone may have little noticeable effect when maternal and fetal interests are similar, because a mother's body will readily adjust homeostatic controls to meet her interests and these interests will include the delivery of a healthy offspring. But, when maternal and fetal interests diverge, placental hormones may become critical for offspring survival, but at the expense of mothers' expectations of future reproduction. 


\section{References}

[1] Haig D. Genetic conflicts in human pregnancy. Q Rev Biol 1993;68:495-532.

[2] Haig D. Placental hormones, genomic imprinting, and maternal-fetal communication. J Evol Biol 1996;9:357-380.

[3] Vasilatos-Younken R, Zhou Y, Wang X, McMurtry JP, Rosebrough RW, Decuypere E, et al. Altered chicken thyroid hormone metabolism with chronic GH enhancement in vivo: consequences for skeletal muscle growth. J Endocrinol 2000;166:609-620.

[4] Norbeck LA, Kittilson JD, Sheridan MA. Resolving the growth-promoting and metabolic effects of growth hormone: differential regulation of GH-IGF-1 system components. Gen Comp Endocrinol 2007;151:332-341.

[5] Scacchi M, Pincelli AI, Cavagnini F. Nutritional status in the neuroendocrine control of growth hormone secretion: the model of anorexia nervosa. Frontiers Neuroendocrinol 2003;24:200-224.

[6] Riddle O, Bates RW, Dykshorn SW. The preparation, identification and assay of prolactin - a hormone of the anterior pituitary. Am J Physiol 1933;105:191-216.

[7] Chilton BS, Mani SK, Bullock DW. Servomechanism of prolactin and progesterone in regulating uterine gene expression. Mol Endocrinol 1988;2:1169-1175.

[8] Young KH, Kraeling RR, Bazer FW. Effects of prolactin on conceptus survival and uterine secretory activity in pigs. J Reprod Fert 1989;86:713-722.

[9] Jones RL, Critchley HOD, Brooks J, Jabbour HN, McNeilly AS. Localization and temporal expression of prolactin receptor in human endometrium. J Clin Endocrinol Metab 1998;83:258-262.

[10] Frasor J, Gaspar CA, Donnelly KM, Gibori G, Fazleabas AT. Expression of prolactin and its receptor in the baboon uterus during the menstrual cycle and pregnancy. J Clin Endocrinol Metab 1999;84:3344-3350.

[11] Stewart MD, Johnson GA, Gray CA, Burghardt RC, Schuler LA, Joyce MM, et al. Prolactin receptor and uterine milk protein expression in the ovine endometrium during the estrous cycle and pregnancy. Biol Reprod 2000;62:1779-1789.

[12] Gerlo S, Davis JRE, Mager DL, Kooijman R. Prolactin in man: a tale of two promoters. BioEssays 2006;28:1051-1055.

[13] Handwerger S, Richards RG, Myers SE. Autocrine/paracrine regulation of decidual prolactin expression. In: Soares MJ, Handwerger S, Talamantes F, editors. Trophoblast Cells. Pathways for Maternal-Embryonic Communication. New York: Springer-Verlag; 1993. p. 134-150. 
[14] Gubbay O, Critchley HOD, Bowen JM, King A, Jabbour HN. Prolactin induces ERK phosphorylation in epithelial and $\mathrm{CD} 56^{+}$natural killer cells of the human endometrium. J Clin Endocrinol Metab 2002;87:2329-2335.

[15] Burton GJ Jauniaux E, Charnock-Jones DS. Human early placental development: potential roles of the endometrial glands. Placenta 2007;28(Suppl A):S64-69.

[16] Bole-Feysot C, Goffin V, Edery M, Binart N, Kelly PA. Prolactin (PRL) and its receptor: actions, signal transduction pathways and phenotypes observed in PRL receptor knockout mice. Endocr Rev 1998;19:225-268.

[17] Roberts RL, Jenkins KT, Lawler T, Wegner FH, Newman JD. Bromocriptine administration lowers serum prolactin and disrupts parental responsiveness in common marmosets (Callithrix j. jacchus). Horm Behav 2001;39:106-112.

[18] Shingo T, Gregg C, Enwere E, Fujikawa H, Hassam R, Geary C, et al. Pregnancystimulated neurogenesis in the adult female forebrain mediated by prolactin. Science 2003;299:117-120.

[19] Gunnet JW, Freeman ME. The mating-induced release of prolactin: a unique neuroendocrine response. Endocr Rev 1983;4:44-61.

[20] Pau CY, Pau KY, Berria M, Spies HG. Ovarian influence on gonadotropin and prolactin release in mated rabbits. Endocrine 2000;13:25-35.

[21] Krüger THC, Haake P, Hartmann U, Schledowski M, Exton MS. Orgasm-induced prolactin secretion: feedback control of sexual drive? Neurosci Biobehav Rev 2002;26:31-44.

[22] Vance ML, Thorner MO. Prolactin: basic physiology. In: DeGroot LJ, editor. Endocrinology, third edition. Philadelphia: W. B. Saunders; 1995. p. 394-405.

[23] Goffin V, Shiverick KT, Kelly PA, Martial JA. Sequence-function relationships within the expanding family of prolactin, growth hormone, placental lactogen, and related proteins in mammals. Endocr Rev 1996;17:385-410.

[24] Adkins RM, Nekrutenko A, Li WH. Bushbaby growth hormone is much more similar to nonprimate growth hormones than to rhesus monkey and human growth hormones. Mol Biol Evol 2001;18:55-60.

[25] Wallis OC, Zhang YP, Wallis M. Molecular evolution of growth hormone (GH) in primates. Characterisation of the GH genes from slow loris and marmoset defines an episode of rapid evolutionary change. J Mol Endocrinol 2001;26:249-258.

[26] Wallis M. The molecular evolution of vertebrate growth hormones: a pattern of nearstasis interrupted by sustained bursts of rapid change. J Mol Evol 1996;43:93-100.

[27] Wallis OC, Mac-Kwashie AO, Makri G, Wallis M. Molecular evolution of prolactin in primates. J Mol Evol 2005;60:606-614. 
[28] Li Y, Wallis M, Zhang Y. Episodic evolution of prolactin receptor gene in mammals: coevolution with its ligand. J Mol Endocrinol 2005;35:411-419.

[29] Peckham WD, Hotchkiss J, Knobil E, Nicoll CS. Prolactin activity of homogeneous primate growth hormone preparations. Endocrinology 1968;82:1247-1248.

[30] Scammell JG, von Haven R, Friesen HG, Wear LB, Thompson ME, Brady AG, et al. Characterization of prolactin and growth hormone immuno- and bioactivities in the pituitary gland and serum of the squirrel monkey (Saimiri boliviensis boliviensis). Am J Primatol 1992;26:35-46.

[31] González Alvarez R, Revol de Mendoza A, Esquivel Escobedo D, Corrales Félix G, Rodríguez Sánchez I, González V, et al. Growth hormone locus expands and diverges after the separation of New and Old World monkeys. Gene 2006;380:3845.

[32] Chen EY, Liao YC, Smith DH, Barrera-Saldaño HA, Gelinas RE, Seeburg PH. The human growth hormone locus: nucleotide sequence, biology, and evolution. Genomics 1989;4:479-497.

[33] Musicki B, Pepe GJ, Albrecht ED. Functional differentiation of placental syncytiotrophoblasts during baboon pregnancy: developmental expression of chorionic somatomammotropin messenger ribonucleic acid and protein levels. $\mathrm{J}$ Clin Endocrinol Metab 1997;82:4105-4110.

[34] Li Y, Ye C, Shi P, Zou XJ, Xiao R, Gong YY, Zhang YP. Independent origin of the growth hormone gene family in New World monkeys and Old World monkeys/ hominoids. J Mol Endocrinol 2005;35:399-409.

[35] Lowman HB, Cunningham BC, Wells JA. Mutational analysis and protein engineering of receptor-binding determinants in human placental lactogen. J Biol Chem 1991;266:10982-10988.

[36] Solomon G, Reicher S, Gussakovsky EE, Jomain JB, Gertler A. Large-scale preparation and in vitro characterization of biologically active human placental (20 and $22 \mathrm{~K})$ and pituitary $(20 \mathrm{~K})$ growth hormones: placental growth hormones have no lactogenic activity in humans. Growth Horm IGF Res 2006;16:297-307.

[37] Stefaneanu L, Kovacs K, Lloyd RV, Scheithauer BW, Young WF, Sano T, Jin L. Pituitary lactotrophs and somatotrophs in pregnancy: a correlative in situ hybridization and immunocytochemical study. Virchows Arch B 1992;62:291-296.

[38] Mirlesse V, Frankenne F, Alsat E, Poncelet M, Hennen G, Evain-Brion D. Placental growth hormone levels in normal pregnancy and in pregnancies with intrauterine growth retardation. Pediat Res 1993;34:439-442. 
[39] Wu Z, Bidlingmaier M, Friess SC, Kirk SE, Buchinger P, Schiessl B, Strasburger CJ. A new nonisotopic, highly sensitive assay for the measurement of human placental growth hormone: development and clinical implications. J Clin Endocrinol Metab 2003;88:804-811.

[40] Goodman HM, Tai LR, Ray J, Cooke NE, Liebhaber SA. Human growth hormone variant produces insulin-like and lipolytic responses in rat adipose tissue. Endocrinology 1991;129:1779-1783.

[41] Barbour LA, Shao J, Qiao L, Pulawa LK, Jensen DR, Bartke A, et al. Human placental growth hormone causes severe insulin resistance in transgenic mice. Am J Obstet Gynecol 2002;186:512-517.

[42] Mertani HC, Garcia-Caballero T, Lambert A, Gerard F, Palayer C, Boutin JM, et al. Cellular expression of growth hormone and prolactin receptors in human breast disorders. Int J Cancer 1998;79:202-211.

[43] Tarrade A, Kuen RL, Malassine A, Tricottet V, Blain P, Vidaud M, Evain-Brion D. Characterization of human villous and extravillous trophoblasts isolated from first trimester placenta. Lab Invest 2001;81:1199-1211.

[44] Hoshina M, Boothby M, Boime, I. Cytological localization of chorionic gonadotropin $\alpha$ and placental lactogen mRNAs during development of the human placenta. J Cell Biol 1982;93: 190-198.

[45] Wallis M. Variable evolutionary rates in the molecular evolution of mammalian growth hormones. J Mol Evolution 1994;38:619-627.

[46] Wallis M. Episodic evolution of protein hormones: molecular evolution of pituitary prolactin. J Mol Evolution 2000;50:465-473.

[47] Colosi P, Thordarson G, Hellmiss R, Singh K, Forsyth IA, Gluckman P, Wood WI. Cloning and expression of ovine placental lactogen. Mol Endocrinol 1989;3:14621469.

[48] Larson JH, Kumar CG, Everts RE, Green CA, Evert-van der Wind A, Band MR, Lewin HA. Discovery of eight novel divergent homologs expressed in cattle placenta. Physiol Genomics 2006;25:405-413.

[49] Ushizawa K, Takahashi T, Hosoe M, Kizaki K, Abe Y, Sasada H, et al. Gene expression profiles of novel caprine placental prolactin-related proteins similar to bovine placental prolactin-related proteins. BMC Dev Biol 2007;7:e16.

[50] Gertler A, Djiane J. Mechanism of ruminant placental lactogen action: molecular and in vivo studies. Mol Genet Metab 2002;75:189-201. 
[51] Biener E, Martin C, Daniel N, Frank SJ, Centonze VE, Herman A, et al. Ovine placental lactogen-induced heterodimerization of ovine growth hormone and prolactin receptors in living cells is demonstrated by fluorescence resonance energy transfer microscopy and leads to prolonged phosphorylation of signal transducer and activator of transcription (STAT)1 and STAT3. Endocrinology 2003;144:35323540 .

[52] Noel S, Herman A, Johnson GA, Gray CA, Stewart MD, Bazer FW, et al. Ovine placental lactogen specifically binds to endometrial glands of the ovine uterus. Biol Reprod 2003;68:772-780.

[53] Song G, Bazer FW, Wagner GF, Spencer TE. Stanniocalcin (STC) in the endometrial glands of the ovine uterus: regulation by progesterone and placental hormones. Biol Reprod 2006;4:913-922.

[54] Spencer TE, Gray A, Johnson GA, Taylor KM, Gertler A, Gootwine E, et al. Effects of recombinant ovine interferon tau, placental lactogen, and growth hormone on the ovine uterus. Biol Reprod 1999;61:1409-1418.

[55] Byatt JC, Wallace CR, Bremel RD, Collier RJ, Bolt DJ. The concentration of bovine placental lactogen and the incidence of different forms in fetal cotyledons and in fetal serum. Domest Anim Endocrinol 1987;4:231-241.

[56] Kessler MA, Duello TM, Schuler LA. Expression of prolactin-related hormones in the early bovine conceptus, and potential for paracrine effect on the endometrium. Endocrinology 1991;129:1885-1895.

[57] Gluckman PD, Kaplan SL, Rudolph AM, Grumbach MM. Hormone ontogeny in the ovine fetus. II. Ovine chorionic somatomammotropin in mid- and late gestation in the fetal and maternal circulations. Endocrinology 1979;104:1828-1833.

[58] Wallis OC, Wallis M. Molecular evolution of growth hormone (GH) in Cetartiodactyla: cloning and characterisation of the gene encoding $\mathrm{GH}$ from a primitive ruminant, the chevrotain (Tragulus javanicus). Gen Comp Endocrinol 2001;123:62-72.

[59] Maniou Z, Wallis OC, Wallis M. Episodic molecular evolution of pituitary growth hormone in Cetartiodactyla. J Mol Evolution 2004;58:743-753.

[60] Wallis M, Lioupis A, Wallis OC. Duplicate growth hormone genes in sheep and goat. J Mol Endocrinol 1998;21:1-5.

[61] Gootwine E. Placental hormones and fetal-placental development. Anim Reprod Sci 2004;82-83:551-566.

[62] Soares MJ, Konno T, Alam SMK. The prolactin family: effectors of pregnancydependent adaptations. Trends Endocrinol Metab 2007;18:114-121. 
[63] Zhong L, Parmer TG, Robertson MC, Gibori G. Prolactin-mediated inhibition of $20 \alpha$-hydroxysteroid dehydrogenase gene expression and the tyrosine kinase system. Biochem Biophys Res Comm 1997;235:587-592.

[64] Galosy SS, Talamantes F. Luteotropic actions of placental lactogens at midpregnancy in the mouse. Endocrinology 1995;136:3993-4003.

[65] Thordarson G, Villalobos R, Colosi P, Southard J, Ogren L, Talamantes F. Lactogenic response of cultured mouse mammary epithelial cells to mouse placental lactogen. J Endocrinol 1986;109:263-274.

[66] Jackson D, Volpert OV, Bouck N, Linzer DIH. Stimulation and inhibition of angiogenesis by placental proliferin and proliferin-related protein. Science 1994;266:1581-1584.

[67] Linzer DIH, Fisher SJ. The placenta and the prolactin family of hormones: regulation of the physiology of pregnancy. Mol Endocrinol 1999;13:837-840.

[68] Ma GT, Linzer DIH. GATA-2 restricts prolactin-like protein A expression to secondary trophoblast giant cells in the mouse. Biol Reprod 2000;63:570-574.

[69] Ain R, Tash JS, Soares MJ. Prolactin-like protein A is a functional modulator of natural killer cells at the maternal-fetal interface. Mol Cell Endocrinol 2003;204:6574.

[70] Ain R, Dai G, Dunmore GH, Godwin AR, Soares MJ. A prolactin family paralog regulates reproductive adaptations to a physiological stressor. Proc Natl Acad Sci U S A 2004;101:16543-16548.

[71] Parks JS. Molecular biology of growth hormone. Acta Paed Scand Suppl 1989;349:127-135. 